\title{
THE STIMULATION OF MALE DUCT DERIVATIVES IN FEMALE GUINEA-PIGS WITH AN ANTIANDROGEN, CYPROTERONE ACETATE
}

\author{
K.-J. GRÄF, R.-L. KLEINECKE AND F. NEUMANN \\ Department of Endocrinpharmacology, Research Laboratories, Schering $A G$, \\ Berlin/Bergkamen, Germany*
}

(Received 3rd September 1973)

\begin{abstract}
Summary. Pregnant guinea-pigs were given cyproterone acetate intramuscularly from the 15 th to the 40 th day post coitum (p.c.). The dose for each group was 50,75 or $100 \mathrm{mg} / \mathrm{kg} /$ day. On the 46 th day p.c., the fetuses were removed and the internal and external genitalia of the genetically female guinea-pigs were examined. Virilization effects were seen in all the female fetuses examined; there was stimulation of the epididymal tubules, development of the Wolffian ducts and prostate, but no stimulation of the seminal vesicles. There was distinct virilization of the external genitalia; the vagina was considerably shortened in favour of the sinus urogenitalis. The balanopreputial fold was completely closed over in some animals, resembling that normally found in the external genitalia of male guinea-pig fetuses. It was not possible to influence the differentiation of the gonads or the Müllerian ducts. These effects were not dose-dependent, and it was not possible to reach any conclusions about this paradoxical masculinizing action of cyproterone acetate, although a number of possible explanations are discussed.
\end{abstract}

\section{INTRODUGTION}

Many investigations have been undertaken to discover what rôle sex hormones play in sexual differentiation. The techniques have involved the administration of synthetic sex hormones or the extirpation or transplantation of endocrine organs. Such experiments have indicated that sex hormones play an important part in sexual differentiation, although some processes do not seem to be under the control of known hormones.

The discovery of the highly effective antiandrogen, cyproterone acetate (Hamada, Neumann \& Junkmann, 1963), provided a further useful tool for investigating the effect of endogenous androgens on sexual differentiation. Numerous experiments with this substance in various mammals confirmed the theory of Wiesner (1935) in accordance with the hypothesis of Jost (1947, 1955) that the testes produce at least one other sexual inductor, apart from androgens, which is essential for the regression of the Müllerian ducts.

* Postal address: Schering AG, 1 Berlin 65, Müllerstrasse 170-172, West Germany. 
In this study, the effect of the application of cyproterone acetate on the somatic sexual differentiation in female guinea-pig fetuses is presented.

\section{MATERIALS AND METHODS}

Three groups of guinea-pigs, aged 4 to 6 months, were mated during oestrus. The presence of spermatozoa in the vaginal smears was taken to indicate that mating had been successful. The animals were then treated with cyproterone acetate (6-chloro- 17 -acetoxy- $1 \alpha, 2 \alpha$-methylene-4,6-pregnadiene-3,20-dione), which was dissolved in benzyl benzoate: castor oil in the ratio $1: 10 \mathrm{v} / \mathrm{v}$. The drug was injected intramuscularly at the dosage rates and for the period shown in Table 1. The treatment was carried out during the 'critical phases' of sexual differentiation (Gräf \& Neumann, 1972).

Table 1. Scheme showing the treatment schedule of pregnant guinea-pigs with CPA and the numbers of fetuses examined

\begin{tabular}{c|c|c|c|c}
\hline Group & \multicolumn{2}{|c|}{\begin{tabular}{c} 
No. of fetuses studied \\
\cline { 2 - 3 }
\end{tabular}} & $\begin{array}{r}\text { Male } \\
\text { CPA } \\
(m g / k g / \text { day })\end{array}$ & $\begin{array}{c}\text { Period of treatment } \\
\text { (days p.c.) }\end{array}$ \\
\hline 0 & 8 & 10 & 0 & 15 to $40^{*}$ \\
1 & 0 & 7 & 50 & 15 to 40 \\
2 & 0 & 6 & 75 & 15 to 40 \\
3 & 0 & 9 & 100 & 15 to 40 \\
\hline \multicolumn{4}{c}{ GPA = Cyproterone acetate; p.c. = post coitum. } \\
* Controls; injected with solvent only.
\end{tabular}

On Day 46 post coitum (p.c.), the fetuses were removed, dissected and eviscerated, particular care being taken with the internal and external genital organs. The genetically female fetuses were fixed in Bouin's solution for approximately 20 days. Before the histological preparation took place, the external genital organs were separated from the rest of the reproductive tract by means of a horizontal cut through the urethral axis. After the organs had been embedded in paraffin wax, serial sections were prepared with a mean thickness of $5 \mu \mathrm{m}$. Every 20th section in the tract, and every 5 th section in the area of the phallus was stained with haematoxylin and eosin and then examined with a light microscope.

For the examination of adult animals, a fourth group of parent animals was given a daily intramuscular dose of $50 \mathrm{mg} / \mathrm{kg}$ cyproterone acetate from Day 25 to Day 45 p.c. The offspring were reared and examined when they became adult.

\section{RESULTS}

All the guinea-pig fetuses examined showed distinct signs of virilization of the genital tracts but no clear dose-response relationship was recognizable. The ovaries, oviducts and uteri proved to be largely unresponsive to prenatal exposure to cyproterone acetate. 


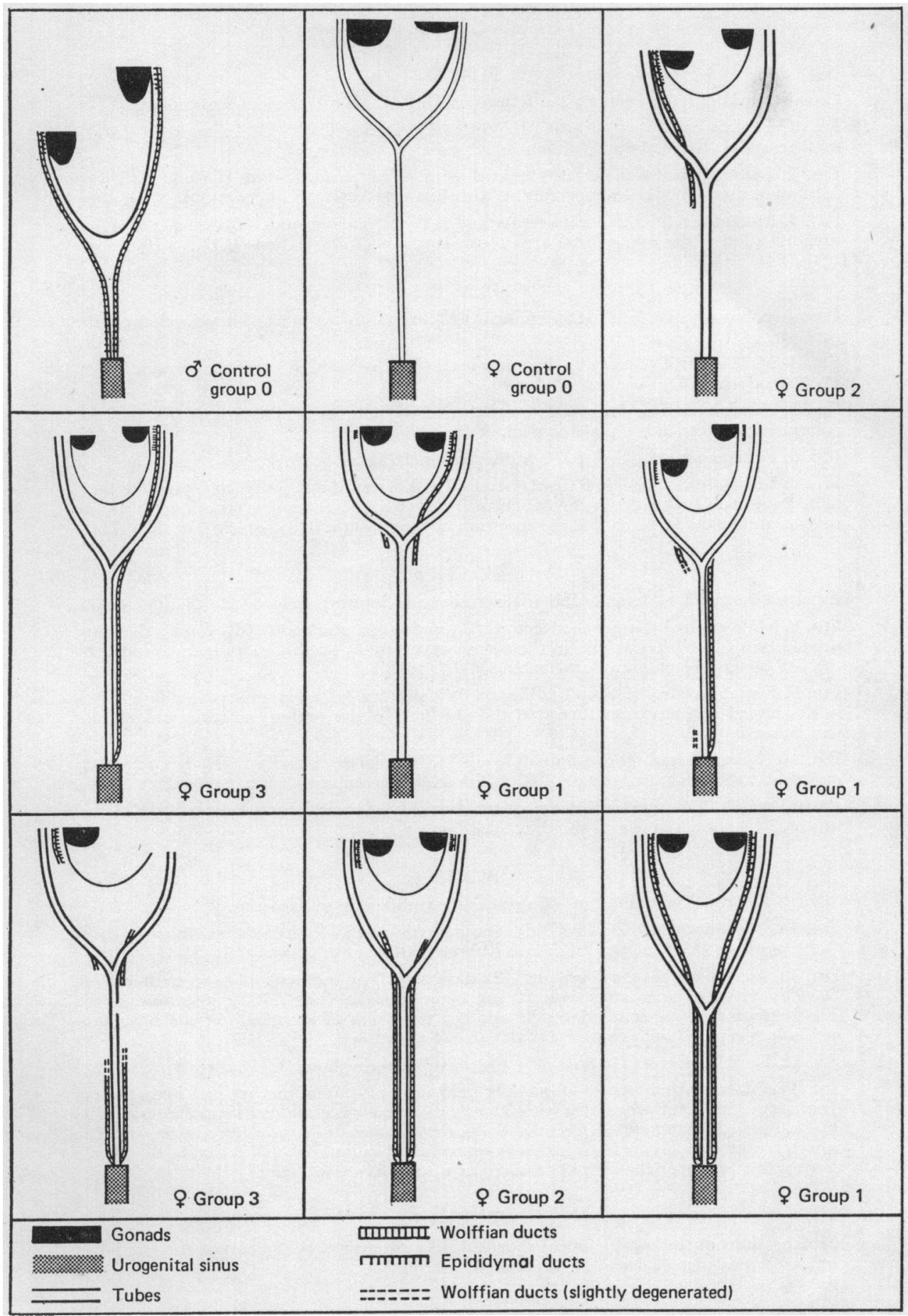

Text-FIG. 1. Scale drawings showing the possible developments in the reproductive tract of female guinea-pig fetuses after treatment with cyproterone acetate. 


\section{EXPLANATION OF PLATES 1 TO 5}

\section{PLATE 1}

Cross-sections of female guinea-pig fetuses on Day 46 of embryonic development.

Fig. 1. Female control (Group 0). Rectum (R), ureter (UR), Müllerian duct (MD), mesogenitalia $(M)$ without Wolffian duct. $\times 40$.

Fig. 2. Masculinized female fetus treated with cyproterone acetate (Group 3). Fused Müllerian ducts (FMD), mesogenitalia with bilateral Wolffian ducts (WD). $\times 64$.

FIG. 3. Masculinized female fetus treated with cyproterone acetate (Group 3). A higher magnification of the mesogenital area containing the Wolffian duct (WD). $\times 100$.

\section{PLATE 2}

Cross-sections of male and female guinea-pig fetuses showing marked development of the prostate.

Frg. 4. Male control (Group 0). Prostate buds (PB), rectum (R), seminal vesicle (SV), Wolffian duct (WD), urethra $(U) . \times 40$.

Fig. 5. Feminized male fetuses. The number of prostate buds (PB) are clearly reduced compared to those of the male control. $\times 40$.

FIG. 6. Female control (Group 0). Müllerian duct (MD). $\times 40$.

FIG. 7. Masculinized female fetuses (Group 3). Wolffian ducts (WD) and prostate buds (PB) appear on both sides of the Müllerian duct (MD). The level of stimulated prostate buds is almost the same as that of regression of the prostate buds seen in Fig. $5 . \times 40$.

\section{PLATE 3}

External genitalia of female and male guinea-pig fetuses; view of the phallic region. Fig. 8. Male control (Group 0). Rectum (R) and bursa perinealis (BP) fused; the sinus urogenitalis (SUG) lies axially in the corpus cavernosum urethrae and is surrounded by the completely closed glans lamella ring (GL). $\times 18$.

FrG. 9. Female control (Group 0). Vagina (V), urethra (U). The glans lamella (GL) is sickle-shaped and does not surround the urethra. In this region, no sinus urogenitalis can be seen. $\times 18$.

Fig. 10. Masculinized female fetus (Group 1). The glans lamella (GL) is completely closed and the sinus urogenitalis $(S U G)$ lies axially (compare to Fig. 8). $\times 18$.

Frgs 11 to 13. Enlargement of the glans lamella (GL), sinus urogenitalis (SUG) and urethra (U) shown in Figs 8 to $10 . \times 56$.

\section{PLATE 4}

Sexual organs of adult male and female guinea-pigs.

Frg. 14. Male control (226 days old). Seminal vesicle (SV), testis (T), urinary bladder (UB), prostate (PR), penis (P), ductus deferens (DD), sinus urogenitalis (SUG).

FIG. 15. Feminized male guinea-pig ( 423 days old). The mother had been treated from Days 25 to 45 of pregnancy with $50 \mathrm{mg}$ cyproterone acetate/day/kg intramuscularly. The regression of the seminal vesicle and the reduction of the length of the sinus urogenitalis compared with that of a male control are shown.

Fig. 16. Female control (418 days old). Ovary (O), uterine horn (UH), corpus uteri (CU). Fig. 17. Masculinized female guinea-pig ( 423 days old). The mother had been treated from Days 25 to 45 of pregnancy with $50 \mathrm{mg}$ cyproterone acetate/day $/ \mathrm{kg}$ intramuscularly. The stabilized left ductus deferens and the development of a prostate are shown. The length of the sinus urogenitalis is clearly extended by comparison with that of the female control but is shorter than that of treated or untreated males (see Figs 14 to 16).

\section{PLATE 5}

Cross-sections of the uterine horns shortly before the fusion to the corpus uteri in adult female guinea-pigs on Day 196 after birth.

Fig. 18. Female control. Uterine horn (UH) $\times 40$.

Frg. 19. Masculinized guinea-pig. The mother had been treated from Days 25 to 45 of pregnancy with $50 \mathrm{mg}$ cyproterone acetate $/$ day $/ \mathrm{kg}$ intramuscularly. The persistent unilateral ductus deferens (DD) is shown. $\times 40$. 
PLATE
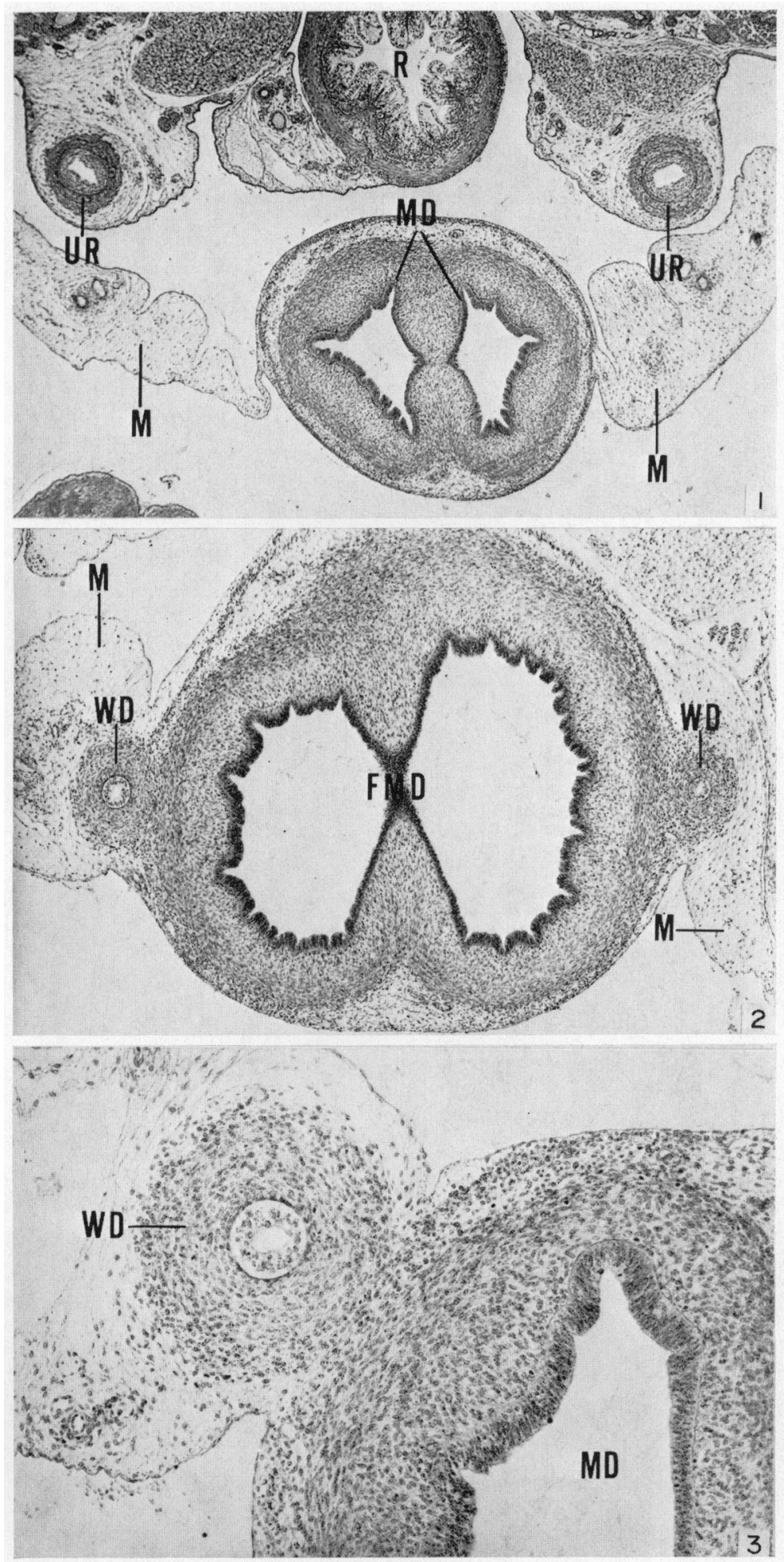
PLATE, 2
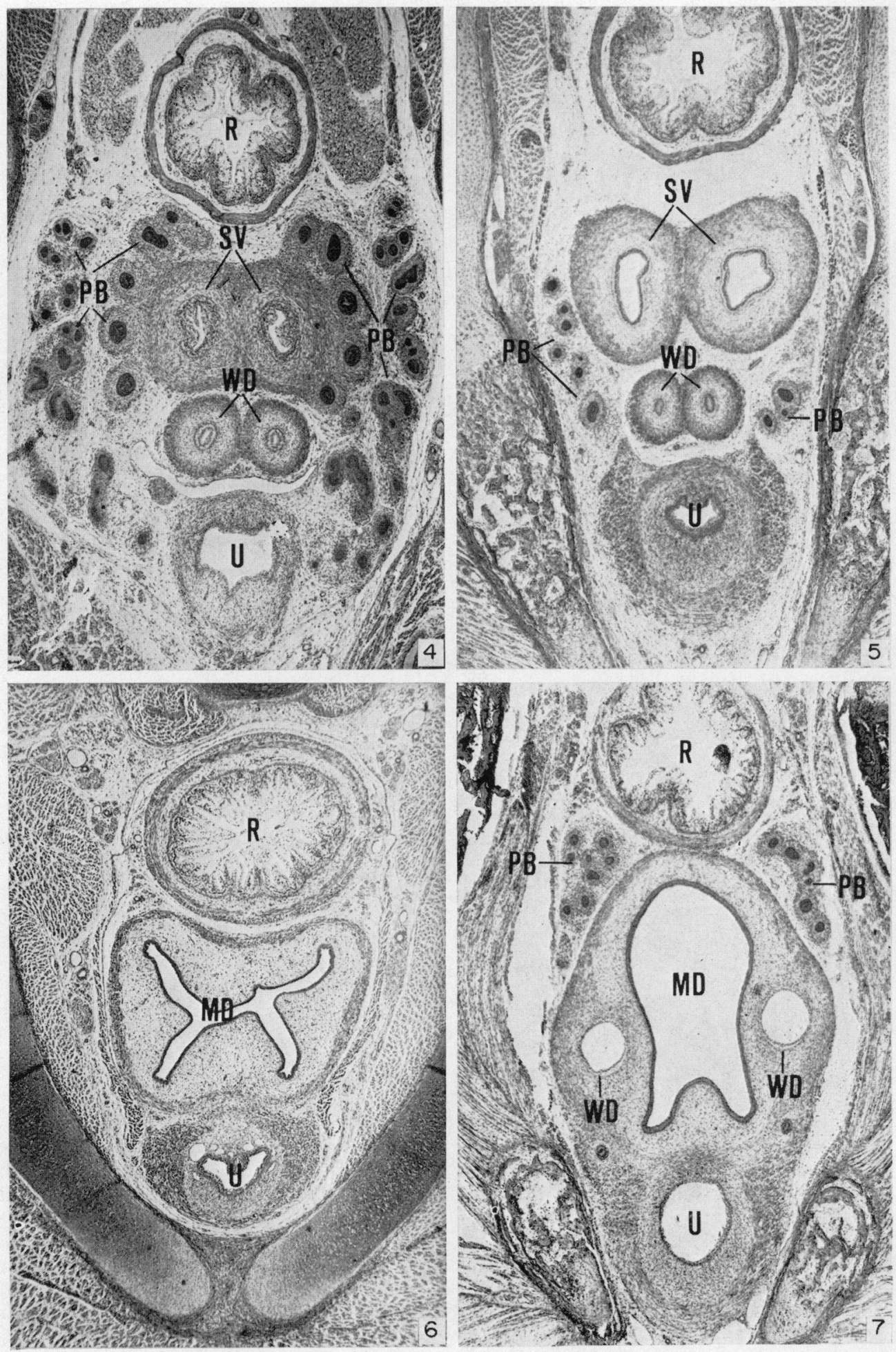
PLATE 3
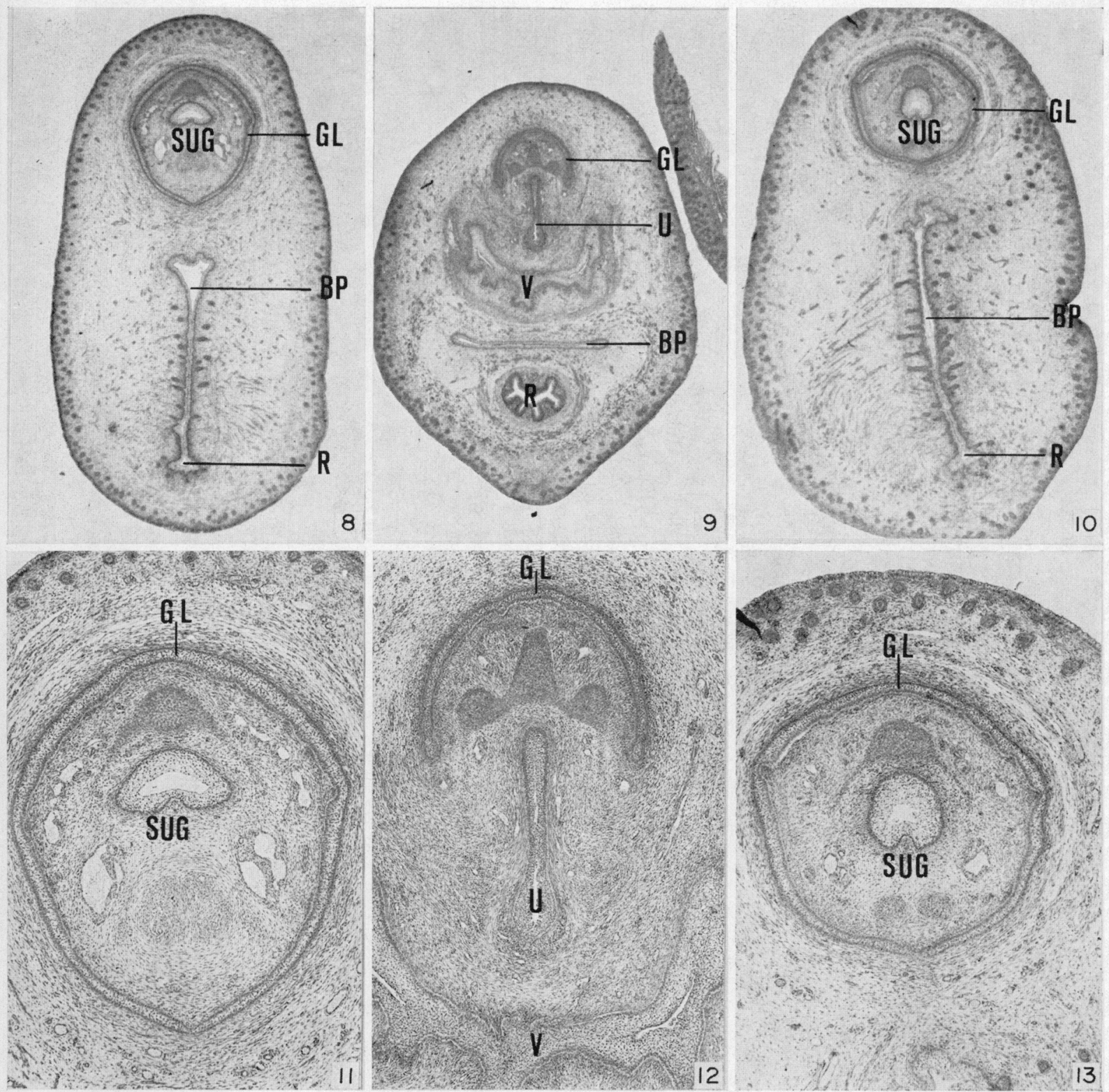

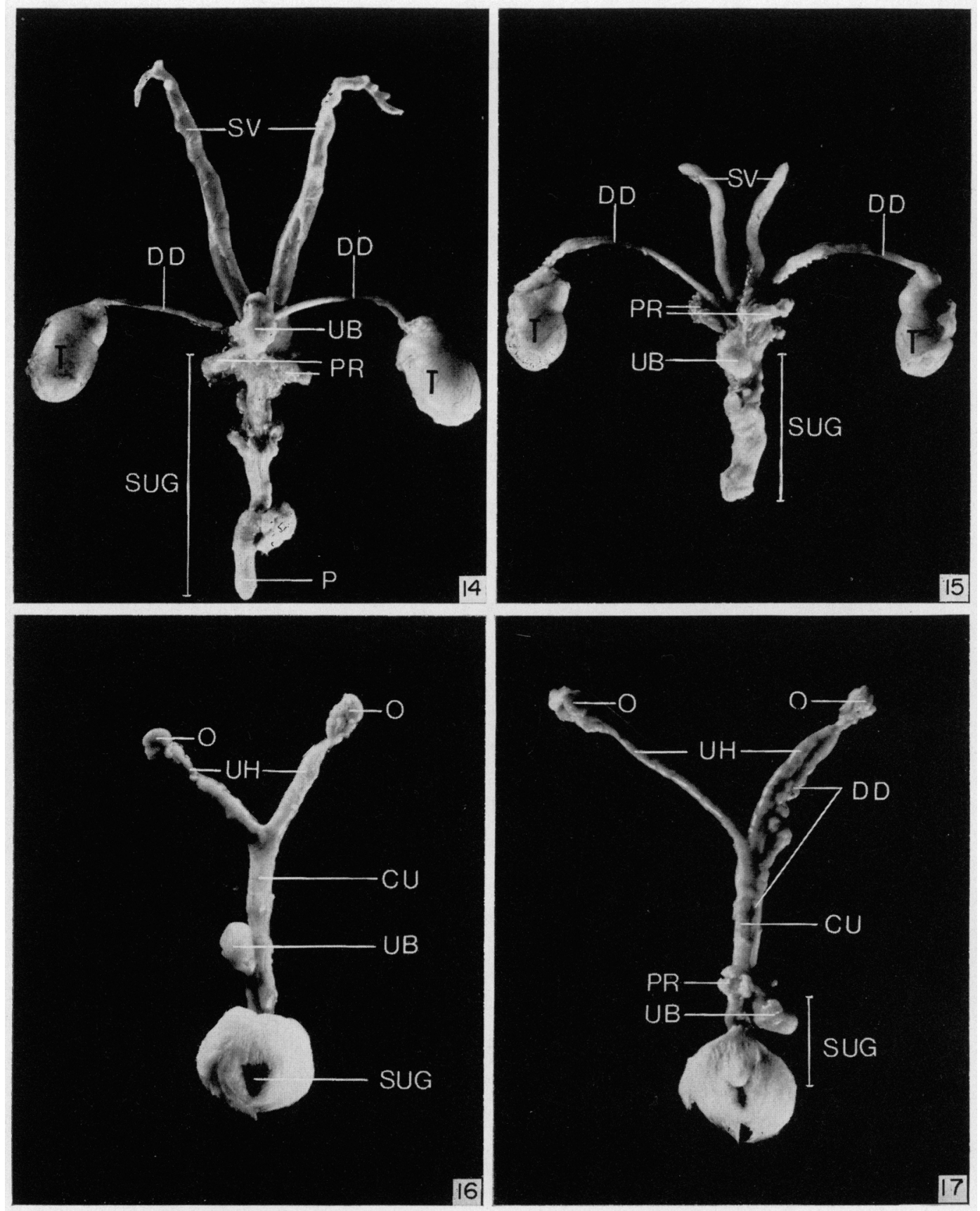
PLATE 5
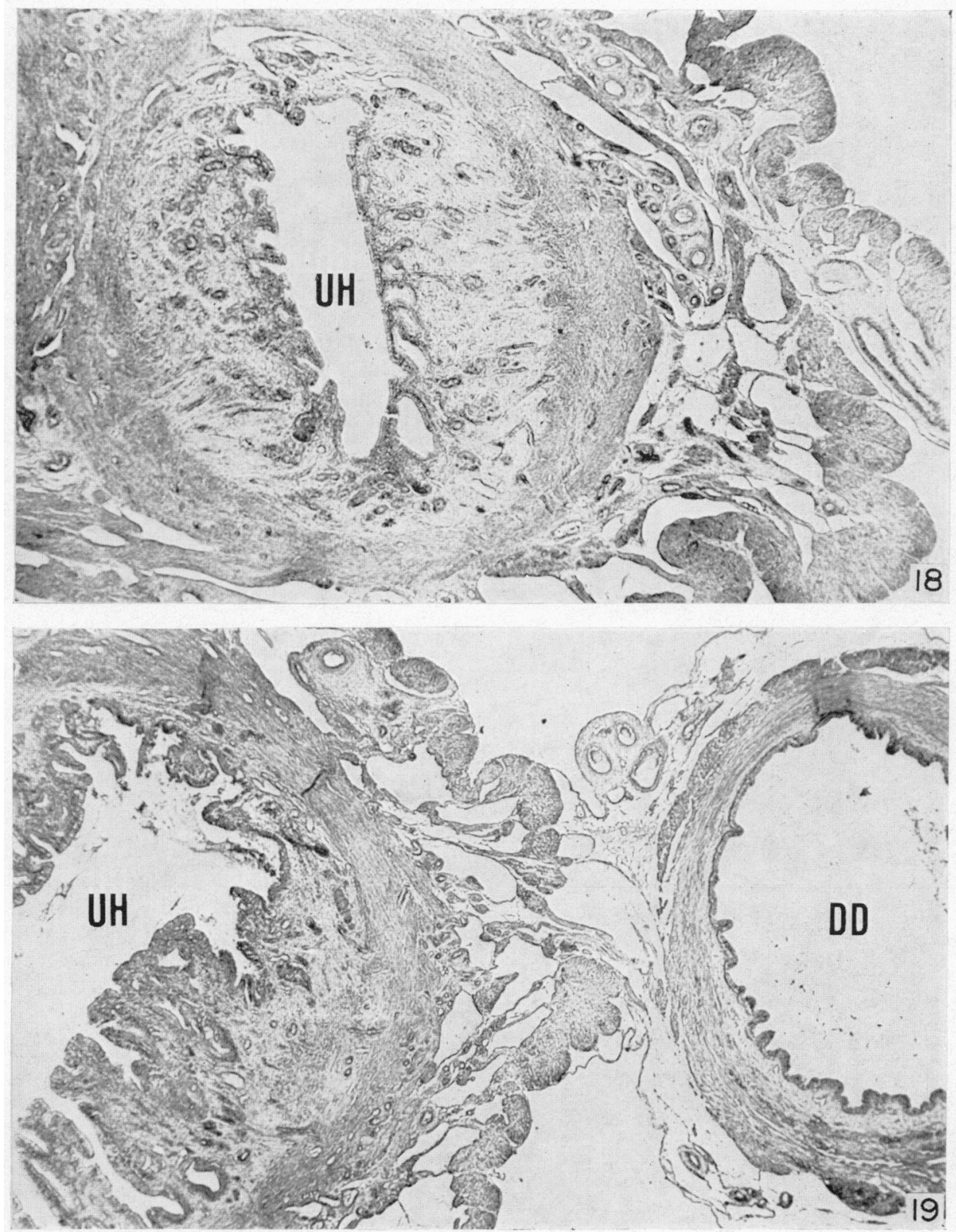
All the female fetuses that had been exposed to cyproterone acetate neonatally showed good development of the normally vestigial Wolffian duct system and in some fetuses this development was extensive. There was full bilateral development with connections to well-developed epididymal tubules, which normally remain rudimentary. In other fetuses, the development was unilateral or there was incomplete development of the duct system in the cranio-caudal area. There was no evidence for the preferential development of any part of the duct system (Text-fig. 1; Pl. 1, Figs 1 to 3; Pl. 2, Fig. 7).

The prostate gland complexes were also well developed in all female fetuses in the three dosage groups. The extent of the proliferation of these complexes never reached the stage of development of the male control animals (Text-fig. 2; Pl. 2, Figs 4 to 7). In Text-fig. 2, the number of cross-sections, of prostate buds was counted in every 20th section to give an estimate of the degree of prostate development.

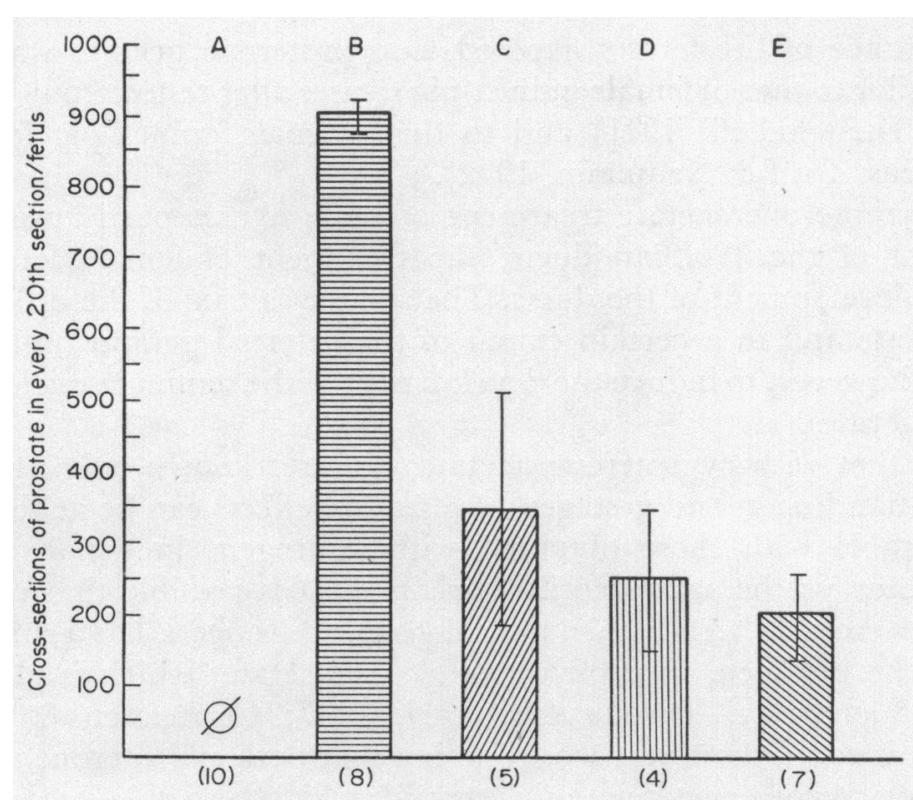

TEXT-FIG. 2. The development of prostatic buds in guinea-pig fetuses treated with cyproterone acetate. A: $\$$ Control group 0 (no prostate); B: o Control group 0; C: o Group 1, $50 \mathrm{mg} \mathrm{CPA} / \mathrm{kg} /$ day; D: $\%$ Group 2, $75 \mathrm{mg} \mathrm{GPA} / \mathrm{kg} /$ day; E: $q$ Group 3, $100 \mathrm{mg}$ $\mathrm{GPA} / \mathrm{kg} /$ day. Vertical lines and bars represent the standard deviation. Figures in parentheses are numbers of animals studied. CPA $=$ cyproterone acetate.

In female control animals, the sinus urogenitalis became the common excretory duct of the vagina and the urethra only when it reached the region of the phallus. In the fetuses of Groups 1 to 3, the sinus urogenitalis reached a length which more nearly corresponded to the proportions in male control animals. The common duct reached as far as the caudal pole of the prostate in the pelvic area. As a result of this, the vaginae and urethrae in the treated 
female fetuses were considerably shortened in favour of the sinus urogenitalis (P1. 3, Figs 8 to 10).

The balanopreputial fold in normal female guinea-pigs is horseshoe-shaped and surrounds the urethra. In males, it completely surrounds the sinus urogenitalis. In some of the fetuses of Groups 1 to 3, this fold showed distinct signs of virilization. The fold was completely closed and the enlarged sinus urogenitalis was situated in the middle of the balanopreputial fold cylinder (Pl. 3, Figs 8 to 13). The morphological effects of fetal virilization were irreversible, as could be seen from animals allowed to mature after their mothers had been treated with cyproterone acetate (Pl. 4, Figs 14 to 17; Pl. 5). If the Wolffian ducts and prostate gland complexes had developed during the fetal stage, they continued to grow after birth quite normally in proportion to the rest of the body and did not degenerate in adulthood.

\section{DISCUSSION}

The appearance of the fetuses exposed to cyproterone acetate was in many respects similar to that of female guinea-pig fetuses after testosterone propionate treatment (Dantchakoff, 1941) and to that of male guinea-pig fetuses after antiandrogens (Gräf \& Neumann, 1972).

Whilst cyproterone acetate treatment of male fetuses partly prevented the development of the Wolffian ducts, the treatment of female fetuses partly stimulated development of the ducts. The same was true of the differentiation of the prostate and to a certain extent of the external genital organs. It was impossible, however, to induce the development of the seminal vesicles in female guinea-pig fetuses.

The fact that with cyproterone acetate, hitherto known only as a strongly effective antiandrogen and gestagen, virilization effects can be achieved which are comparable with those obtained with androgens in female guinea-pig fetuses, cannot yet be satisfactorily explained. It is possible that cyproterone acetate, because of its well-known partial gestagenic effects, has a similar action to that of the gestagen, medroxyprogesterone acetate, which is also strongly virilizing (Suchowsky, Turolla \& Arcari, 1967; Cupceancu \& Neumann, 1969). In this connection, it is worth noting that both cyproterone acetate and medroxyprogesterone acetate are $\mathrm{C}_{21}$ steroids which, as a rule, have gestagenic and corticoid effects but do not have an androgenic effect.

With the exception of slight virilization effects such as were described for genetically female rabbit fetuses (Elger, 1966), cyproterone acetate has hitherto shown no signs of inducing virilization effects in numerous experiments (Neumann \& Hamada, 1963; Hamada et al., 1963; Neumann, Richter \& Günzel, 1965; Neumann, Elger \& Kramer, 1966; Neumann, Elger \& Steinbeck, 1970; Elger, Neumann, Steinbeck \& Hahn, 1970; Elger, Steinbeck, Cupceancu \& Neumann, 1970). It may well be that the virilization effects achieved here were 'paradoxical' effects, since the dosages used in our experiments were much larger than the physiological dose. Cyproterone acetate may only induce antiandrogenic and gestagenic effects in guinea-pigs at low dosages and androgenic effects may begin to appear only at very high concentrations. 


\section{REFERENGES}

Gupceancu, B. \& Neumann, F. (1969) Sensibilitätsunterschiede der verschiedenen Strukturen des Genitaltraktes von weiblichen Rattenfoeten unter dem Einfluss von Medroxyprogesteronacetat oder Norethisteronacetat. Endokrinologie, 54, 66.

Dantchakopr, V. (1941) Der Aufbau des Geschlechts beim höheren Wirbeltier, pp. 25-33, 45-48, 311-314. Gustav Fischer Verlag, Jena.

ELGER, W. (1966) Die Rolle der foetalen Androgene in der Sexual-differenzierung des Kaninchens und ihre Abgrenzung gegen andere hormonelle und somatische Faktoren durch Anwendung eines starken Antiandrogens. Archs Anat. microsc. Morph. exp. 55, 658.

Elger, W., Neumann, F., Steinbeck, H. \& Hahn, J. D. (1970) The significance of hormones in mammalian sex differentiation as evidenced by experiments with synthetic androgens and antiandrogens. In Mammalian Reproduction, pp. 33-44. Eds. H. Gibian and E. J. Plotz. Heidelberg, Berlin.

Elger, W., Steinbeck, H., Gupceancu, B. \& Neumann, F. (1970) Influence of methyltestosterone and cyproterone acetate on Wolffian duct differentiation in female rat foetuses. 7. Endocr. 47, 417.

GRÄF, K.-J. \& NEUMANN, F. (1972) Influence of cyproterone acetate on sexual differentiation of male guinea pigs. Z. Anat. EntwGesch. 137, 200.

Hamada, H., Neumann, F. \& Junkmann, K. (1963) Intra-uterine antimaskuline Beeinflussung von Rattenfoeten durch ein stark gestagen wirksames Steroid. Acta endocr., Copenh. 44, 380.

Jost, A. (1947) Recherches sur la différenciation sexuelle de l'embryon de lapin. I. Introduction et embryologie génitale normale. II. Action des androgènes de synthèse sur l'histogenèse génitale. III. Rôle des gonades foetales dans la différenciation sexuelle somatique. Archs Anat. microsc. Morph. exp. 36, 151, 242, 271.

Jost, A. (1955) Modalities in the action of gonada land gonad-stimulating hormones in the foetus. Mem. Soc. Endocr. 4, 237.

Neumans, F. \& Hamada, H. (1963) Intra-uterine Feminisierung männlicher Rattenfoeten durch das stark gestagen wirksame 6 -chlor- $\Delta^{6}-1,2 \alpha$-methylen-17 $\alpha$-hydroxy-progesteronacetat. Proc. 10 th Symp. D. Gesell. Endocr., Wien. "Schilddrüsenhormone und körperperipherie Regulation der Schilddrüsenfunktion", p. 301.

NeumanN, F., Richter, U.-D. \& Günzed, P. (1965) Wirkungen von Antiadrogenen. Zentbl. Med. $12,171$.

Neumann, F., Elger, W. \& Kramer, M. (1966) The development of a vagina in male rats by inhibiting the androgen receptors with an antiandrogen during the critical phase of organogenesis. Endocrinology, 78, 628.

Neumann, F., Elger, W. \& Steinbeck, H. (1970) Antiandrogen and reproductive development. Phil. Trans. R. Soc. B, 259, 179.

Suchowsky, G. K., Turolla, E. \& Arcari, G. (1967) Studies of the so-called virilizing effects of steroids in female rat fetuses. Endocrinology, 80, 255.

Wiesner, B. P. (1935) The postnatal development of the genital organs in the albino rat with a discussion of a new theory of sexual differentiation. F. Obstet. Gynaec. Br. Emp. 41, 867; 42, 8. 